\title{
Provocações, reflexões e originalidade
}

O volume 27, número 3, de 2013, da Revista Brasileira de Educação Física e Esporte - RBEFE revela mais uma vez nosso compromisso com a pluralidade da área de Educação Física e Esporte, e a preocupação com a disseminação do conhecimento em diferentes dimensões e abrangências. Ademais, damos continuidade à publicação de ensaios que contribuem substancialmente para reflexões e discussões pertinentes à nossa área de conhecimento. Assim como nos números anteriores, os ensaios aqui publicados nos remetem a essas reflexões, por conta de provocaçōes elegantemente estruturadas e apresentadas por seus autores. $\mathrm{O}$ ensaio intitulado "O ensino de habilidades motoras esportivas na escola e o esporte de alto rendimento: discurso, realidade e possibilidades" de Tani e colaboradores, é leitura obrigatória para toda a nossa comunidade, tanto para docentes e pesquisadores no universo da Academia, quanto para os profissionais envolvidos diretamente nesse processo. Não menos provocativo, o ensaio "Metabolic regulation during sports events: factual interpretations and inadequate allegations" de Poortmans e Carpentier, aborda importantes aspectos da regulação metabólica nos eventos esportivos e estimula os leitores a uma aprofundada imersão na temática. Além disso, destaco a pluralidade, a qualidade, e a originalidade dos artigos publicados neste número, nas três subáreas da RBEFE, contemplando, mais uma vez, as demandas e interesses de nossa área.

Prof. Dr. Alexandre Moreira

Blog da RBEFE - http://rbefe.blogspot.com.br 